\title{
Analisis Pengaruh Transparansi dan Akuntabilitas Keuangan Daerah terhadap Kinerja Organisasi Perangkat Daerah \\ (Studi pada Badan Pengelola Keuangan dan Aset Daerah Kab Tegal, BUMD Kab Tegal, Ikatan Profesi Notariat Kab Tegal, Camat dan Lurah Kab Tegal)
}

\author{
Chifniyatul Ulya dan Ernawati Budi Astuti* \\ Jurusan Akuntansi, Fakultas Ekonomi, Universitas Wahid Hasyim Semarang \\ Jalan Menoreh Tengah X/22, Sampangan, Semarang \\ "Email: erna.fe@unwahas.ac.id
}

\begin{abstract}
Abstrak
Penelitian ini bertujuan untuk mengetahui pengaruh persepsi anggota legislatif daerah terhadap transparansi dan akuntabilitas keuangan daerah terhadap kinerja pemerintah daerah. Penilaian persepsi didasarkan pada indikator yang mencerminkan kondisi yang transparan dan akuntabel. Sampel diambil dari populasi keseluruhan dengan pertimbangan populasi yang relatif kecil (kurang dari 100) maka semua perubahan dapat diambil sebagai populasi keseluruhan. Penelitian ini menggunakan data primer yang diperoleh rekapitulasi dari kuesioner yang telah diberikan kepada responden. Alur analisis dimulai dari uji data kualitatif dan berlanjut ke uji asumsi klasik dan yang terakhir adalah pengujian hipotesis. Hasil pengujian hipotesis penelitian ini menunjukkan bahwa transparansi berpengaruh positif, sedangkan akuntabilitas berpengaruh negatif terhadap kinerja kinerja pemerintah daerah.
\end{abstract}

Kata kunci: Akuntabilitas, Kinerja pemerintah, Transparansi

\section{PENDAHULUAN}

Pencapaian kinerja pemerintah daerah yang baik memerlukan akuntabilitas, transparansi keuangan daerah agar kinerja pemerintah daerah baik dan memuaskan. Penerapan aturan perundang-undangan yang terkait dengan penerapan konsep akuntabilitas dan transparansi dalam pengelolaan keuangan diharapkan dapat mewujudkan pengelolaan pemerintah daerah yang baik. Implementasi akuntabilitas dan transparansi dalam pengelolaan keuangan daerah ini diharapkan mampu meningkatkan kinerja pemerintah daerah.

Keuangan daerah dimanfaatkan untuk mendukung penyelenggaraan urusan pemerintahan daerah. Sehingga hal tersebut dapat terwujud secara optimal bila diikuti dengan adanya sumbersumber penerimaan daerah yang memadai dengan mengacu pada peraturan perundang-undangan yang berlaku. Untuk itu pengelolaan keuangan daerah menjadi salah satu pokok permasalahan yang harus mendapat perhatian dalam penyelenggaraan fungsi pemerintahan daerah. Anggaran Pendapatan dan Belanja Daerah (APBD) merupakan implementasi dari pengelolaan keuangan daerah. Sehingga untuk dapat mengetahui gambaran pengelolaan keuangan daerah dapat dilakukan dengan melakukan analisis terhadap pelaksanaan APBD dan laporan keuangan pemerintah daerah sekurang-kurangnya dalam kurun waktu 5 (lima) tahun sebelumnya. Dari hasil analisis tersebut dapat diperoleh gambaran tentang kapasitas atau kemampuan keuangan daerah dalam mendanai penyelenggaraan pembangunan daerah. Petunjuk pelaksanaan pengelolaan keuangan daerah di Kabupaten Tegal yang merupakan dasar operasional adalah mengacu pada Peraturan Daerah Kabupaten Tegal Nomor 4 Tahun 2015 tentang Pokok-Pokok Pengelolaan Keuangan Daerah. Sesuai dengan Peraturan Menteri Dalam Negeri Nomor 13 tahun 2006 tentang Pedoman Pengelolaan Keuangan Daerah maka asas umum pengelolaan keuangan daerah yang telah menjadi komitmen pemerintah daerah Kabupaten Tegal adalah keuangan daerah dikelola secara tertib, taat pada peraturan perundang-undangan, efektif, efisien, ekonomis, transparan dan bertanggung jawab denganmemperhatikan asas keadilan, kepatutan, dan manfaat untuk masyarakat (www.tegalkab.go.id).

Anggaran pendapatan dan belanja daerah kabupaten tegal tidak berjalan sendiri dalam mengemban tugasnya untuk mengembangkan daerahnya, serta untuk mewujudkan cita-cita bangsa yakni keadilan sosial bagi seluruh rakyat Indonesia. Pemerintah daerah sebagai mitra yang melaksanakan fungsi kepemerintaan daerah (Rido:2015). 
Konsep akuntabilitas menurut Mardiasmo (2009) merupakan konsep yang lebih luas dari stewardship. Stewardship mengacu pada pengelolaan atas suatu aktivitas secara ekonomi dan efisien tanpa dibebani kewajiban untuk melaporkan, sedangkan akuntabilitas mengacu pada pertanggungjawaban oleh seorang steward kepada pemberi tanggung jawab.

Teori keagenan merupakan suatu kondisi di mana prinsipal memberikan wewenang kepada agen, yang nantinya akan menjalankan amanat prinsipal sesuai ketentuan yang diberikan (Mack dan Ryan, 2006). Halim dan Abdullah (2006) menyatakan bahwa di pemerintah daerah terdapat hubungan dan masalah dalam pelimpahan wewenang (keagenan). Keterkaitan prinsipal dengan agen dapat diketahui dengan melacak proses-proses anggaran (Moe, 1984). Hal ini menandakan bahwa dalam pengelolaan pemerintah daerah, khususnya dalam penyusunan anggaran berbasis kinerja, mengindikasikan munculnya asimetri informasi, yang muncul dalam teori keagenan, antara masyarakat atau DPRD sebagai principal dan pihak eksekutif (SKPD) yang bertindak sebagai agen (pengelola pemerintahan) sehingga dalam penyusunan anggaran diperlukan prinsip akuntabilitas dan transparansi di dalamnya.

Konsep akuntabilitas dalam penelitian ini dapat dijelaskan menggunakan agency theory, dimana dalam pengertian luas akuntabilitas dapat dipahami sebagai kewajiban pihak pemegang amanah dalam hal ini pemerintah (agent) untuk memberikan pertanggungjawaban, menyajikan, melaporkan, dan mengungkapkan segala aktivitas dan kegiatan yang menjadi tanggung jawabnya kepada pihak pemberi amanah dalam hal ini masyarakat yang diwakili oleh DPRD (principal) yang memiliki hak dan kewenangan untuk meminta pertanggungjawaban.

Karakteristik utama hubungan keagenan terletak pada kontrak pelimpahan wewenang dan tanggungjawab dari prinsipal kepada agen. Jensen dan Meckling (1976) menyatakan bahwa hubungan keagenan dapat terjadi pada semua entitas yang mengandalkan pada kontrak, baik eksplisit ataupun implisit, sebagai acuan pranata perilaku partisipan. Oleh karena itu, dapat dikatakan bahwa hubungan keagenan terjadi pada setiap entitas.

Sedangkan fenomena terkait dengan transparansi publik, buku I LHP BPK atas Laporan Keuangan Pemerintah Kabupaten Bungo Tahun 2014 (LHP Laporan Keuangan), Nomor: 34.A/LHP/XVIII.JMB/5/2015, Tanggal 25 Mei 2015) juga mengungkapkan masih ditemukan adanya kerugian, ketidakhematan, ketidak efektifan dalam pengelolaan keuangan daerah. Alokasi belanja daerah juga belum berorientasi kepada kepentingan publik, belanja daerah masih sebagian besar dialokasikan untuk belanja pegawai. Dengan temuan tersebut transparansi terhadap pengelolaan keuangan daerah masih belum menjadi kenyataan (Hari, 2016).

Beberapa penelitian yang terkait dengan fenomena tersebut telah banyak dilakukan. Penelitian yang dilakukan Siregar (2011) menunjukkan bahwa akuntabilitas publik dan transparansi publik berpengaruh signifikan terhadap pengelolaan APBD Kota Pematang Siantar, sedangkan pengawasan tidak berpengaruh secara signifikan terhadap pengeloaan APBD Kota Pematang Siantar. Berbeda hasil penelitian yang dilakukan Suparno (2012), dalam penelitiannya menunjukkan akuntabilitas dan transparansi tidak berpengaruh signifikan terhadap pengelolaan keuangan daerah Kota Dumai, sedangkan pengawasan berpengaruh terhadap pengeloaan keuangan daerah Kota Dumai.

Berdasarkan uraian diatas peneliti ingin meneliti transparansi dan akuntabilitas memiliki pengaruh terhadap kinnerja organisasi perangkat daerah dengan sampel pegawai pemerintah dan instansi yang menggunakan hasil laporan keuangan daerah di kabupaten Tegal dengan judul "ANALISIS PENGARUH TRANSPARANSI, AKUNTABILITAS KEUANGAN DAERAH TERHADAP KINERJA ORGANISASI PERANGKAT DAERAH" (Studi Pada BPKAD Kabupaten Tegal, BUMD Kab Tegal, Ikatan Profesi Notariat, Camat dan Lurah Kab Tegal).

\section{Kinerja Organisasi Perangkat Daerah}

Organisasi Perangkat Daerah (OPD) merupakan Instansi Pemerintah Daerah yang menerima dan menggunakan anggaran untuk menjalankan tugas pokok dan fungsinya, oleh karena itu mempunyai kewajiban untuk membuat akuntabilitas keuangan. Akuntabilitas keuangan Instansi Pemerintah Daerah Kabupaten atau Kota merupakan suatu perwujudan pertanggungjawaban suatu Instansi Pemerintah Daerah atas pelaksanaan Anggaran Pendapatan dan Belanja Daerah (APBD) kabupaten atau kota dalam menjalankan program dan kegiatan untuk melaksanakan misi organisasi guna mencari tujuan dan sasaran yang telah ditetapkan. 
Berdasarkan Peraturan Pemerintah No. 105 Tahun 2000 Pasal 20 Ayat 1 dan 2, tolak ukur kinerja Pemda adalah ukuran keberhasilan yang dicapai pada setiap unit organisasi perangkat daerah. Bastian (2006) mendefinisikan kinerja sebagai prestasi yang dicapai oleh organisasi dalam periode tertentu. Kinerja merupakan pencapaian atas apa yang direncanakan, baik oleh pribadi maupun organisasi (Hamzah, 2008). Penelitian yang dilakukan Azhar (2008) mengungkapkan bahwa kinerja diartikan sebagai aktivitas terukur dari suatu entitas selama periode tertentu sebagai bagian dari ukuran keberhasilan pekerjaan. Adapun menurut Mulyadi (2000:419) penilaian kinerja organisasi yaitu "penentuan secara periodik efektivitas operasional suatu organisasi, bagian organisasi dan karyawannya, berdasarkan sasaran, standar dan kriteria yang telah ditetapkan sebelumnya".

Dalam konteks organisasi pemerintah daerah, pengukuran kinerja pimpinan OPD dilakukan untuk menilai seberapa baik Pimpinan OPD tersebut melakukan tugas pokok dan fungsi yang dilimpahkan kepadanya selama periode tertentu. Pengukuran kinerja pimpinan SKPD merupakan wujud dari vertical accountability yaitu pengevaluasian kinerja bawahan oleh atasannya dan sebagai bahan horizontal accountability pemerintah daerah yaitu kepada masyarakat atas amanah yang diberikan kepadanya (Mangkuprawira, 2004:225).

Organisasi Perangkat Daerah merupakan pusat pertanggungjawaban yang dipimpin oleh kepala organisasi dan bertanggung jawab atas entitasnya, misalnya: dinas kesehatan, dinas pendidikan, dinas pemuda dan olahraga dan lainnya. Kumorotomo (2005:103), mengungkapkan kinerja organisasi publik adalah hasil akhir (output) organisasi yang sesuai dengan tujuan organisasi, transparan dalam pertanggungjawaban, efisien, sesuai dengan kehendak pengguna jasa organisasi, visi dan misi organisasi, berkualitas, adil, serta diselenggarakan dengan sarana dan prasarana yang memadai.

Indikator-indikator yang digunakan dalam pengukuran ini menurut Nico Andriyanto (2007) yaitu:

1. Penetapan kinerja,

2. Pengukuran kinerja

3. Pencapaian kinerja (output)

4. Pencapaian kinerja (outcome)

5. Penyajian informasi kinerja

6. Pemanfaatan informasi kinerja.

\section{Transparansi dan Akuntabilitas Pengertian Transparansi}

Kerangka konseptual Standar Akuntansi Pemerintahan (2005) menyatakan bahwa pengertian tentang transparansi adalah sebagai berikut:

"Transparency is to provide financial information that is open and honest with public on the basis that the public has a right to know in an open and through on government accountability in the management of the resources entrusted to it and obedience to the laws and regulations. While accountability is accountable for the management of resources and the implementation of policy is entrusted to the reporting entity in achieving the goals set periodically".

Menurut Badan Perencanaan Pembangunan Nasional dan Departemen Dalam Negeri dalam Loina Lalolo Krina P (2003), Transparansi merupakan prinsip yang menjamin akses atau kebebasan bagi setiap orang untuk memperoleh informasi tentang penyelenggaraan pemerintahan, yakni meliputi informasi tentang kebijakan, proses pembuatan dan pelaksanaannya, serta hasil-hasil yang dicapai. Transparansi yakni adanya kebijakan terbuka bagi pengawasan, sedangkan yang dimaksud dengan informasi adalah informasi mengenai setiap aspek kebijakan pemerintah yang dapat dijangkau oleh publik. Keterbukaan informasi diharapkan akan menghasilkan persaingan politik yang sehat, toleran, dan kebijakan dibuat berdasarkan pada preferensi publik. Transparansi berarti suatu keterbukaan secara nyata, menyeluruh, dan memberi ruang kepada seluruh lapisan masyarakat untuk berpartisipasi secara aktif dalam proses pengelolaan sumber daya publik. Apabila dikaitkan dengan anggaran, transparansi dapat didefinisikan sebagai keterbukaan kepada 
masyarakat yang meliputi fungsi dan struktur pemerintah, tujuan kebijakan fiskal, sektor keuangan publik, dan proyeksi-proyeksinya (Nico Andrianto, 2007: 20).

Transparansi pada akhirnya akan menciptakan horizontal accountability antara pemerintah daerah dengan masyarakat sehingga tercipta pemerintahan daerah yang bersih, efektif, efisien , akuntabel dan responsif terhadap aspirasi dan kepentingan masyarakat.

Beberapa manfaat penting adanya transparansi anggaran yaitu dapat mencegah terjadinya korupsi, mudah dalam mengidentifikasi kelemahan dan kekuatan kebijakan, meningkatkan akuntabilitas pemerintah sehingga masyarakat akan lebih mampu mengukur kinerja pemerintah, meningkatkan kepercayaan terhadap komitmen pemerintah untuk memutuskan kebijakan tertentu, menguatkan kohesi sosial, karena kepercayaan publik terhadap pemerintah akan terbentuk, dan menciptakan iklim investigasi yang lebih baik sehingga dapat meningkatkan kepastian usaha (Nico Andrianto, 2007: 21).

Peran media menjadi sangat penting bagi transparansi pemerintah, baik sebagai sebuah kesempatan untuk berkomunikasi pada publik maupun menjelaskan berbagai informasi yang relevan, juga sebagai "watchdog" atas berbagai aksi pemerintah dan perilaku menyimpang dari para aparat birokrasi. Namun media tidak akan dapat melakukan tugas ini tanpa adanya kebebasan pers, bebas dari intervensi pemerintah maupun pengaruh kepentingan bisnis. Keterbukaan membawa konsekuensi adanya kontrol yang berlebih-lebihan dari masyarakat dan bahkan oleh media masa, karena itu, kewajiban akan keterbukaan harus diimbangi dengan nilai pembatasan, yang mencakup kriteria yang jelas dari para aparat publik tentang jenis informasi apa saja yang mereka berikan dan pada siapa informasi tersebut diberikan (Nico Andrianto, 2007:21).

Indikator-indikator yang digunakan dalam pengukuran ini menurut Nico Andriyanto (2007) yaitu:

1. Komunikasi publik oleh pemerintah

2. Hak masyarakat terhadap akses informasi

3. Ketepatan dalam pelaporan

4. Kualitas informasi yang di sampaikan.

\section{Pengertian Akuntabilitas}

Definisi dari akuntabilitas menurut (Gray et al., 1996 dalam Masiyah, 2008) adalah :

"Accountability is the duty of an entity to use (and prevent the misuse) of the resources entrusted it in a effective, efficient and economical manner, within the boundaries of the moral and legal framework of the society and to provide an acoount of its actions to accountees who are not only the persons who provided it with its financial resources but to groups within society and society at large".

Akuntabilitas apabila dikaitkan dengan organisasi pemerintahan, dapat didefinisikan sebagai suatu pemberian informasi atas aktivitas dan kinerja pemerintah kepada pihak-pihak yang berkepentingan (stakeholder), baik pusat maupun daerah, harus bisa menjadi subjek pemberi informasi dalam rangka pemenuhan hak-hak publik.

Dalam konteks penyelenggaraan pemerintahan, akuntabilitas pemerintah tidak dapat diketahui tanpa pemerintah memberitahukan kepada rakyat tentang informasi sehubungan dengan pengumpulan sumber daya dan sumber dana masyarakat beserta penggunaannya. Menurut Kim (2008 : 2) mendefinisikan akuntabilitas sebagai berikut:

"Accountability is basically the obligation to perform as expected or bear the consequences of failure. Accountability is also defined as, " $A$ is accountable to $B$ when $A$ is obliged to inform $B$ about A's actions or decisions".

Dengan kata lain akuntabilitas adalah kewajiban yang pada dasarnya melaksanakan seperti yang diharapkan atau membawa konsekuensi terhadap suatu kegagalan. Akuntabilitas juga dapat digambarkan seperti "A dikatakan akuntabel kepada B ketika A berkewajiban memberi informasi pada B tentang tindakan atau keputusan A.

Akuntabilitas merupakan prinsip pertanggungjawaban yang berarti bahwa proses penganggaran dimulai dari perencanaan, penyusunan, pelaksanaan harus benar-benar dapat dilaporkan dan dipertanggungjawabkan kepada DPRD dan masyarakat. Masyarakat tidak hanya memiliki hak untuk mengetahui anggaran tersebut tetapi juga berhak untuk menuntut pertanggungjawaban atas rencana ataupun pelaksanaan anggaran tersebut (Mardiasmo, 2002). 
Suatu organisasi publik dapat dikatakan akuntabel apabila memenuhi empat dimensi akuntabilitas. Adapun keempat dimensi akuntabilitas yang harus dipenuhi oleh organisasi sektor publik, yaitu:

a. Akuntabilitas kejujuran dan akuntabilitas hukum (accountability for probity and legality).

Akuntabilitas kejujuran (accountability for probity) berkaitan dengan penghindaran penyalah gunaan jabatan (abuse of power), sedangkan akuntabilitas hukum (legal accountability) berkaitan dengan jaminan adanya kepatuhan terhadap hukum dan peraturan lain yang disyaratkan dalam penggunaan sumber dana publik.

b. Akuntabilitas Proses (process accountability)

Akuntabilitas proses terkait dengan prosedur yang digunakan sudah cukup baik atau belum dalam menjalankan tugas, yang meliputi kecukupan sistem informasi akuntansi, sistem informasi manajemen, dan prosedur administrasi. Akuntabilitas proses diwujudkan melalui pemberian pelayanan publik yang cepat, responsif, dan murah biaya. Pengawasan dan pemeriksaan terhadap pelaksanaan akuntabilitas proses dapat dilakukan, misalnya dengan memeriksa ada tidaknya mark up dan pungutan-pungutan lain di luar yang ditetapkan, serta sumber-sumber inefisiensi dan pemborosan yang menyebabkan mahalnya biaya pelayanan publik dan kelambanan dalam pelayanan

c. Akuntabilitas Program (program accountability)

Akuntabilitas program terkait dengan pertimbangan tujuan yang ditetapkan dapat dicapai atau tidak, dan sudah mempertimbangkan alternatif program yang dapat memberikan hasil optimal dengan biaya yang minimal.

d. Akuntabilitas Kebijakan (policy accountability)

Akuntabilitas kebijakan berkaitan dengan pertanggungjawaban pemerintah, baik pusat maupun daerah kepada DPR/DPRD dan masyarakat luas, atas kebijakan-kebijakan yang diambil Ellwood (1993) dalam Mardiasmo (2002: 21).

Meidawati (2012) dalam Rido (2014), menyatakan bahwa akuntabilitas Pemerintah Daerah berpengaruh terhadap kinerja satuan kerja Pemerintah Daerah, hal ini tentu saja akan berpengaruh terhadap kinerja satuan kerja Pemerintah Daerah. Pernyataan tersebut juga didukung oleh penelitian yang dilakukan oleh Rohmah (2003). Hasil dari penelitian terdahulu membuktikan bahwa akuntabilitas dalam pemerintahan daerah diperlukan guna mewujudkan suatu kondisi yang akuntabel dalam pemerintahan daerah. Sehingga dengan terciptanya kondisi yang akuntabel, memudahkan pengawasan atas kinerja pemerintah itu sendiri dan dengan pengawasan yang baik akan menjadi pemicu kinerja pemerintahan yang semakin baik pula.

\section{Tinjauan Keuangan Daerah}

\section{Anggaran Pendapatan dan Belanja Daerah}

Anggaran Pendapatan dan Belanja Daerah berlaku untuk pemerintah provinsi dan kabupaten atau kota. Pembentukan dan pengelolaannya disesuaikan dengan tata cara yang berlaku pada pemerintah pusat. Pendapatan daerah provinsi seperti yang tertulis dalam UU Nomor 28 Tahun 2009, pajak pusat diserahkan kepada daerah pemerintah pusat, antara lain: pajak rumah tangga, pajak kendaraan bermotor, bea balik nama kendaraan bermotor, pajak bahan bakar kendaraan bermotor, pajak air permukaan dan pajak rokok. Pemerintah kabupaten atau kota mendapatkan penghasilan dari berbagai pajak daerah antara lain pajak hotel, pajak restoran, pajak hiburan, pajak reklame, pajak penerangan jalan, pajak mineral bukan logam dan bantuan, pajak parkir, pajak air tanah, pajak sarang burung walet, pajak bumi dan bangunan pedesaan dan perkotaan, dan bea perolehan hak atas tanah dan bangunan.

\section{Pengelolaan Penerimaan Daerah}

Menurut UU No. 32 tahun 2004 pasal 157 dan UU No. 33 tahun 2004 pasal 6, serta PP No. 58 tahun 2005 dan PP No 28 tahun 2009, sumber-sumber penerimaan dapat diperinci sebagai berikut:

1. Pendapatan Asli Daerah (PAD)

Sumber-sumber Pendapatan Asli Daerah merupakan sumber keuangan yang digali dari dalam wilayah yang bersangkutan. Sumber-sumber Pendapatan Asli Daerah terdiri dari : 
a. Pajak Daerah

b. Retribusi Daerah

c. Hasil Perusahaan Milik Daerah

d. Lain-lain Pendapatan Asli Daerah yang sah, antara lain hasil penjualan aset negara dan jasa giro.

2. Dana Perimbangan

Dana perimbangan adalah dana yang bersumber dari penerimaan Anggaran Pendapatan Belanja Daerah (APBD) yang dialokasikan kepada daerah untuk membiayai kebutuhan daerah dalam rangka pelaksanaan desentralisasi. Dana perimbangan tersebut saling mengisidan melengkapi. Adapun pos-pos dana perimbangan tersebut terdiri dari :

a. Bagian daerah dari penerimaan Pajak Bumi dan Bangunan, Bea Perolehan Hak atas Tanah dan Bangunan dan penerimaan dari Sumber Daya Alam

b. Dana Alokasi Umum

c. Dana Alokasi Khusus

d. Lain-lain pendapatan daerah yang sah.

\section{Pengelolaan Pengeluaran Daerah}

Dalam Peraturan pemerintah No. 58 tahun 2005 tentang Pengelolaan Keuangan Daerah, menyebutkan bahwa Pengeluaran Daerah adalah semua pengeluaran kas daerah periode tahun anggaran yang bersangkutan yang meliputi belanja rutin (operasional), belanja pembangunan (belanja modal) serta pengeluaran tidak disangka.

1. Belanja Rutin (Belanja tidak langsung)

Belanja rutin adalah pengeluaran yang manfaatnya hanya untuk satu tahun anggaran dan menambah aset atau kekayaan bagi daerah. Belanja rutin terdiri dari:

1) Belanja pegawai

2) Belanja barang

3) Belanja bunga

4) Belanja subsidi

5) Belanja hibah

6) Belanja bantuan keuangan

7) Belanja operasi dan pemeliharaan sarana prasarana

2. Belanja Investasi atau Pembangunan (Belanja Langsung)

Belanja investasi adalah pengeluaran yang manfaatnya cenderung melebihi satu tahun anggaran dan akan menambah aset atau kekayaan daerah, dan selanjutnya akan menambah anggaran rutin untuk biaya rutin untuk biaya operasional dan pemeliharaannya. Belanja investasi terdiri dari :

a. Belanja modal

b. Belanja aparatur

3. Pengeluaran Tidak Tersangka

Pengeluaran tidak tersangka adalah yang disediakan untuk pembiayaan:

a. Kejadian-kejadian luar biasa seperti bencana alam, kejadian yangdapat membahayakan daerah.

b. Tagihan tahun lalu yang belum diselesaikan dan atau tidak tersedia anggarannya pada tahun yang bersangkutan.

c. Pengambilan penerimaan yang bukan haknya atau penerimaan yang dibebaskan (dibatalkan) dan atau kelebihan penerimaan.

\section{Kemampuan Keuangan Daerah}

Kriteria penting yang lain untuk mengetahui secara nyata kemampuan daerah dalam mengatur dan mengurus rumah tangganya adalah kemampuan daerah dalam bidang keuangan. Dengan perkataan lain, faktor keuangan merupakan faktor yang penting dalam mengatur tingkat kemampuan daerah dalam melaksanakan otonomi daerah. Dalam Peraturan Pemerintah No. 58 tahun 2005, menyebutkan bahwa keuangan daerah adalah semua hak dan kewajiban daerah dalam rangka penyelenggaraan pemerintah daerah yang dapat dinilai dengan uang temasuk didalamnya segala bentuk kekayaan lain yang berhubungan dengan hak dan kewajiban daerah tersebut dalam kerangka APBD. Sehubungan dengan pentingnya posisi keuangan tersebut, keuangan daerah 
sebagai salah satu indikator untuk mengetahui kemampuan daerah dalam mengatur dan mengurus rumah tangganya sendiri.

Dengan dikeluarkannya undang-undang tentang Otonomi Daerah, membawa konsekuensi bagi daerah yang akan menimbulkan perbedaan antar daerah yang satu dengan yang lainnya, terutama dalam hal kemampuan keuangan daerah, antara lain (Nataluddin, 2001: 167):

1) Daerah yang mampu melaksanakan otonomi daerah

2) Daerah yang mendekati mampu melaksanakan otonomi daerah

3) Daerah yang sedikit mampu melaksanakan otonomi daerah dan;

4) Daerah yang kurang mampu melaksanakan urusan otonomi daerah

Selain itu ciri utama yang menunjukkan suatu daerah mampu melaksanakan otonomi daerah adalah sebagai berikut (Nataluddin, 2001:167):

1. Kemampuan keuangan daerah, artinya daerah harus memiliki kewenangan dan kemampuan untuk menggali sumber-sumber keuangan, mengelola dan menggunakan keuangan sendiri yang cukup memadai untuk membiayai penyelenggaraan pemerintahannya.

2. Ketergantungan kepada bantuan pusat harus seminimal mungkin agar Pendapatan Asli Daerah (PAD) harus menjadi bagian sumber keuangan terbesar, yang didukung oleh kebijakan perimbangan keuangan pusat dan daerah, sehingga peranan pemerintah daerah menjadi lebih besar.

\section{Komponen Laporan Keuangan Daerah}

Berdasarkan peraturan Pemerintah Nomor 71 tentang Standar Akuntansi Pemerintah (2010:8), komponen-komponen yang terdapat dalam satu set laporan keuangan berbasis akrual terdiri dari laporan pelaksanaan anggaran (budgetary report) dan laporan finansial, komponen yang dilaporkan adalah sebagai berikut:

1. Laporan Realisasi Anggaran;

2. Laporan Perubahan Saldo Anggaran Lebih;

3. Laporan Operasional;

4. Laporan Perubahan Ekuitas;

5. Neraca;

6. Laporan Arus Kas;

7. Catatan atas Laporan Keuangan.

\section{Transparansi Keuangan Daerah berpengaruh terhadap Kinerja Organisasi Perangkat} Daerah Kabupaten Tegal

Transparansi merupakan hak dasar untuk mengetahui informasi tentang apa yang sedang di programkan oleh pemerintah dan mengapa program tersebut dipilih dan di biayai. Transparansi dibangun atas dasar kebebasan dalam memperoleh informasi yang berkaita dengan kepentingan publik secara langsung di peroleh oleh mereka yang membutuhkan (Mardiasmo, 2009: 18).

Lismawati (2013) menyimpulkan bahwa antara transparansi dan kinerja mempunyai pengaruh yang signifikan positif dimana semakin tinggi tingkat transparansi yang dilakukan oleh Satuan Kerja Pemerintah Daerah di Provinsi Bengkulu maka semakin tinggi juga tingkat kinerja para pegawai di Stasiun Kerja Pemerintah Daerah Provinsi Bengkulu. Hasil penelitian tersebut juga didukung oleh penelitian Rohmah (2012) yang menyimpulkan bahwa transparansi berpengaruh terhadap kinerja partai politik.

$\mathrm{H}_{1}$ : Transparansi Keuangan Daerah berpengaruh signifikan positif terhadap kinerja Organisasi Perangkat Daerah Kabupaten Tegal

\section{Akuntabilitas Keuangan Daerah berpengaruh terhadap Kinerja Organisasi Perangkat} Daerah Kabupaten Tegal

Akuntabilitas keuangan merupakan pertanggungjawaban mengenai integritas keuangan, pengungkapan, dan ketaatan terhadap peraturan perundangan-undangan. Sasaran pertanggungjawaban ini adalah laporan keuangan dan peraturan perundang-undangan yang berlaku mencakup penerimaan, penyimpanan, dan pengeluaran uang oleh instansi pemerintah. 
Pada penelitian yang dilakukan oleh (Meidawati 2012) menyimpulkan bahwa antara akuntabilitas dan kinerja mempunyai pengaruh yang signifikan positif dimana semakin tinggi tingkat akuntabilitas yang dilakukan oleh Satuan Kerja Pemerintah Daerah di Kabupaten Situbondo maka semakin tinggi juga tingkat kinerja para pegawai di Satuan Kerja Pemerintah Daerah di Kabupaten Situbondo. Hal serupa dinyatakan dalam penelitian Hartanti (2011) yang menyatakan bahwa akuntabilitas berpengaruh terhadap kinerja pemerintah daerah di Provinsi Jawa Tengah.

$\mathrm{H}_{2}$ : Akuntabilitas keuangan daerah berpengaruh signifikan positif terhadap kinerja Organisasi Perangkat Daerah Kabupaten Tegal

\section{Transparansi dan Akuntabilitas Keuangan Daerah secara simultan berpengaruh} terhadap Kinerja Organisasi Perangkat Daerah Kabupaten Tegal

Berjalannya reformasi semakin menghidupkan kembali arti demokrasi dalam kehidupan bernegara. Demokrasi identik halnya dengan akuntabilitas. Menerapkan akuntabilitas berarti menerapkan transparansi pula sehingga di antara akuntabilitas dengan transparansi memiliki keterkaitan (Mohamad dkk., 2004:33). Akuntabilitas merupakan kemauan memberikan penjelasan dan justifikasi keinginan dan perbuatan kepada yang berkepentingan (Hunt, 2006:43). Lain hal dengan transparansi yakni mempertanggungjawabkan apa yang telah dilakukan dengan memberi informasi yang relevan atau laporan yang terbuka pada pihak luar atau organisasi mandiri (legislator, auditor, publik) dan dipublikasikan (Haryatmoko, 2011:112). Pada akhirnya, unsur akuntabilitas dan transparansi menjadi suatu kebutuhan di dalam pengelolaan pemerintah termasuk bidang keuangan (Hudayah, 2012), khususnya dalam hal penyusunan anggaran berbasis kinerja.

Adapun penelitian yang dilakukan Citra (2010) menguji pengaruh partisipasi penyusunan anggaran, akuntabilitas dan transparansi kebijakan publik terhadap kinerja manajerial pada Satuan Kerja Perangkat Daerah (SKPD) Dinas se-Kota Semarang. Hasil penelitian ini menunjukkan bahwa partisipasi penyusunan anggaran dan akuntabilitas berpengaruh signifikan sedangkan tranparansi tidak berpengaruh signifikan terhadap kinerja manajerial SKPD Dinas se-Kota Semarang.

Akuntabilitas dan transparansi memiliki karakter yang berbeda. Namun dalam penerapannya, akuntabilitas memiliki kaitan dengan transparansi (Shende dan Bennett, 2004). Hasil riset Meutia dan Nurfitriana (2011) menunjukkan bahwa secara simultan variabel akuntabilitas, transparansi, partisipasi masyarakat, efisiensi dan efektivitas berpengaruh terhadap penyusunan anggaran berbasis kinerja.

$\mathrm{H}_{3}$ : Transparansi dan Akuntabilitas Keuangan Daerah secara simultan berpengaruh positif terhadap kinerja Organisasi Perangkat Daerah Kabupaten Tegal.

Dibawah ini kerangka pemikiran penelitian:

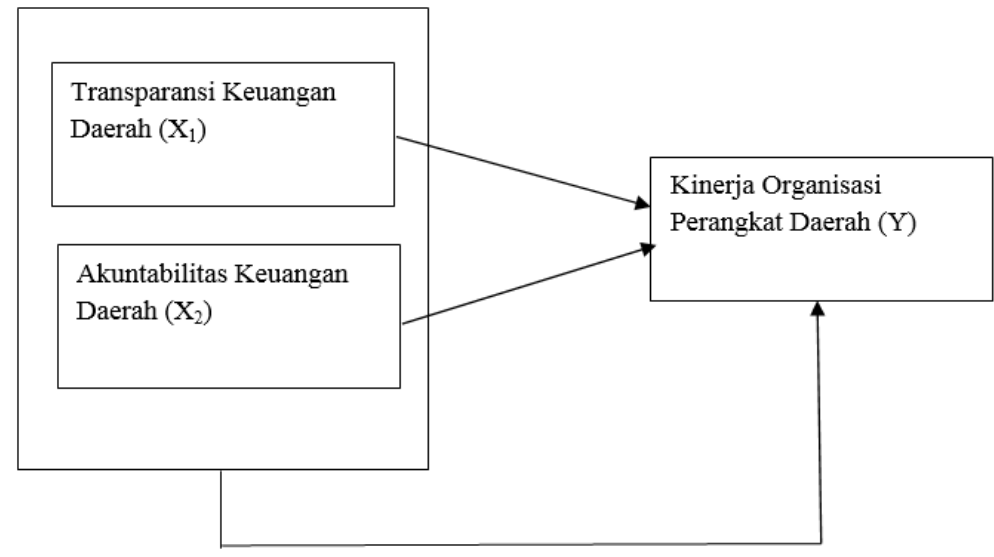

Gambar 1. Kerangka Penelitian 


\section{METODOLOGI PENELITIAN}

\section{Jenis dan Sumber Data}

Jenis data yang digunakan dalam penelitian ini adalah data primer. Data primer merupakan data yang diperoleh peneliti secara langsung dari sumber asli (Indriantoro dan Supomo, 2012:147). Dalam mendapatkan data primer, peneliti harus mengumpulkan data secara langsung sehingga teknik pengumpulan data primer yang digunakan peneliti dalam penelitian ini atau sumber data adalah dengan melakukan penyebaran kuisioner kepada Badan Pengelola Keuangan Dan Aset Daerah Kab Tegal, Bumd Kab Tegal, Ikatan Profesi Notariat Kab Tegal, Camat Dan Lurah Kab Tegal.

\section{Metode Pengumpulan Data}

Metode pengumpulan data primer dalam penelitian ini yaitu menggunakan kuesioner (angket). Kuesioner ditujukan kepada semua Pegawai OPD Badan Pengelolaan Keuangan dan Aset Daerah Kabupaten Tegal, BUMD kab Tegal, Ikatan Profesi Notariat, Camat dan Lurah kab Tegal. Pertanyaan peneliti dan jawaban responden dapat dikemukakan secara tertulis melalui suatu kuesioner. Kuesioner tersebut didistribusikan oleh peneliti secara langsung kepada responden tanpa melalui perantara. Kuesioner dalam penelitian ini dirancang untuk penelitian kuantitatif. Oleh karena itu, bentuk pertanyaan dalam kuesioner bersifat close-ended questions agar memudahkan dalam pengukuran respon. Skala pengukuran respon yang digunakan adalah 5 (lima) poin skala likert.

\section{HASIL DAN PEMBAHASAN Analisis Deskriptif Statistik}

Analisis deskriptif statistik adalah menggambarkan tentang ringkasan data-data penelitian seperti mean, standar deviasi, varian, modus, dll. Analisis deskriptif ini digunakan untuk memberikan penjelasan dalam penelitian lanjutan untuk memberikan hasil yanng lebih baik terhadap analisis regresi. Analisis deskriptif bersifat penjelasan statistik dengan memberikan gambaran data tentang jumlah data, minimum, maksimum, mean, dan standar deviasi (Prayitno, 2010:12).

Tabel 1. Hasil Uji Statistik Deskripstif

\begin{tabular}{|l|l|l|l|l|l|}
\hline & & Min & Max & Mean & $\begin{array}{l}\text { Std. } \\
\text { Deviation }\end{array}$ \\
\hline X1 & 85 & 44.00 & 57.00 & 51.8706 & 3.20635 \\
\hline X2 & 85 & 40.00 & 50.00 & 45.9529 & 2.59994 \\
\hline Y & 85 & 128.00 & 145.00 & $1.3449 \mathrm{E} 2$ & 5.23182 \\
\hline N & 85 & \multicolumn{5}{|c|}{ Sumber: Data diolah, Juni 2018 } \\
\hline \multicolumn{7}{|c|}{}
\end{tabular}

Berdasarkan Tabel 1, berkaitan dengan analisis deskriptif statistik dapat dilihat bahwa dengan jumlah data sebanyak 85, variabel kinerja OPD (Y) mempunyai rata-rata sebesar 1.3449E2, dengan nilai minimal 128.00 dan maksimal 145 , sedangkan standar devisiasinya sebesar $5.231 \%$. Variabel transparansi $\left(\mathrm{X}_{1}\right)$ mempunyai rata-rata 51.87, dengan nilai minimal 44.00 dan maksimal 57.00 , sedangkan standar devisiasinya sebesar $3.206 \%$, variabel akuntabilitas $\left(\mathrm{X}_{2}\right)$ mempunyai ratarata sebesar 45.95 dengan nilai minimal 40.00 dan maksimal 57.00 sedangkan standar devisiasinya sebesar $2.599 \%$.

\section{Uji Validitas}

Uji Validitas dimaksudkan untuk mengetahui seberapa besar ketepatan dan kecermatan suatu alat ukur penelitian dalam melakukan fungsi ukurnya. Uji validitas sebagai alat ukur dalam penelitian ini, yaitu menggunakan korelasi product moment pearson's, yaitu dengan cara mengkorelasikan tiap pertanyaan dengan skor total, kemudian hasil korelasi tersebut dibandingkan dengan angka kritis taraf signifikan 5\% (Prayitno, 2010:90). 
Tabel 2. Hasil Uji Validitas

\begin{tabular}{|lccc|}
\hline Indikator & $\begin{array}{c}\text { product } \\
\text { moment }\end{array}$ & $A$ & Keterangan \\
\hline & pearson's & & \\
\hline X1.1.1 & 0,618 & 0,05 & Valid \\
X1.1.2 & 0,796 & 0,05 & Valid \\
X1.1.3 & 0,810 & 0,05 & Valid \\
X1.2.1 & 0,677 & 0,05 & Valid \\
X1.2.2 & 0,802 & 0,05 & Valid \\
X1.2.3 & 0,794 & 0,05 & Valid \\
X1.3.1 & 0,540 & 0,05 & Valid \\
X1.3.2 & 0,841 & 0,05 & Valid \\
X1.3.3 & 0,743 & 0,05 & Valid \\
X1.4.1 & 0,539 & 0,05 & Valid \\
X1.4.2 & 0,590 & 0,05 & Valid \\
X1.4.3 & 0,530 & 0,05 & Valid \\
X2.1.1 & 0,791 & 0,05 & Valid \\
X2.1.2 & 0,822 & 0,05 & Valid \\
X2.2.1 & 0,559 & 0,05 & Valid \\
X2.2.2 & 0,679 & 0,05 & Valid \\
X2.2.3 & 0,528 & 0,05 & Valid \\
X2.2.4 & 0,588 & 0,05 & Valid \\
X2.3.1 & 0,735 & 0,05 & Valid \\
X2.3.2 & 0,796 & 0,05 & Valid \\
X2.4.1 & 0,817 & 0,05 & Valid \\
X2.4.2 & 0,822 & 0,05 & Valid \\
Y1.1.1 & 0,695 & 0,05 & Valid \\
Y1.1.2 & 0,601 & 0,05 & Valid \\
Y1.1.3 & 0,513 & 0,05 & Valid \\
Y1.1.4 & 0,514 & 0,05 & Valid \\
Y1.1.5 & 0,547 & 0,05 & Valid \\
Y1.1.6 & 0,601 & 0,05 & Valid \\
Y1.2.1 & 0,578 & 0,05 & Valid \\
Y1.2.2 & 0,569 & 0,05 & Valid \\
Y1.2.3 & 0,765 & 0,05 & Valid \\
Y1.2.4 & 0,886 & 0,05 & Valid \\
Y1.3.1 & 0,715 & 0,05 & Valid \\
Y1.3.2 & 0,774 & 0,05 & Valid \\
Y1.3.3 & 0,583 & 0,05 & Valid \\
Y1.3.4 & 0,785 & 0,05 & Valid \\
Y1.3.5 & 0,608 & 0,05 & Valid \\
Y1.4.1 & 0,611 & 0,05 & Valid \\
Y1.4.2 & 0,808 & 0,05 & Valid \\
Y1.4.3 & 0,622 & 0,05 & Valid \\
& 0,829 & 0,05 & Valid \\
Y1.4 & 0,564 & 0,05 & Valid \\
\hline
\end{tabular}




\begin{tabular}{|cccc|}
\hline Indikator & $\begin{array}{c}\text { product } \\
\text { moment } \\
\text { pearson's }\end{array}$ & $A$ & Keterangan \\
\hline Y1.5.2 & 0,638 & 0,05 & Valid \\
Y1.5.3 & 0,582 & 0,05 & Valid \\
Y1.5.4 & 0,602 & 0,05 & Valid \\
Y1.5.5 & 0,952 & 0,05 & Valid \\
Y1.5.6 & 0,503 & 0,05 & Valid \\
Y1.5.7 & 0,540 & 0,05 & Valid \\
Y1.5.8 & 0,540 & 0,05 & Valid \\
Y1.5.9 & 0,542 & 0,05 & Valid \\
Y1.5.10 & 0,557 & 0,05 & Valid \\
Y1.6.1 & 0,702 & 0,05 & Valid \\
Y1.6.2 & 0,538 & 0,05 & Valid \\
Y1.6.3 & 0,589 & 0,05 & Valid \\
\hline \multicolumn{4}{|l}{ Sumber: Data diolah Juni 2018 } \\
\hline
\end{tabular}

\section{Uji Reliabilitas}

Uji reliabilitas adalah lanjutan dari uji validitas dimana hanya item-item yang valid saja yang diuji reliabilitasnya. Uji reliabilitas dilakukan dengan menggunakan metode Cronbach Alpha dengan bantuan software SPSS. Instrumen dapat dikatakan reliabel jika nilai alpha lebih besar dari 0,60 .

Tabel 3. Hasil Uji Reliabilitas

\begin{tabular}{|lrl|}
\hline Variabel & Alpha & Keterangan \\
\hline $\mathrm{X}_{1}$ & 0,703 & Reliabel \\
$\mathrm{X}_{2}$ & 0,715 & Reliabel \\
$\mathrm{Y}$ & 0,737 & Reliabel \\
\hline \multicolumn{2}{l}{ Sumber: Data diolah, Juni 2018 }
\end{tabular}

Berdasarkan Tabel 3 hasil uji reliabilitas diatas menunjukkan bahwa data yang diperoleh bersifat reliabel karena itu nilai cornbach's Alpha yakni 0,703, 0,715, dan 0,737, >0,60, sehingga data yang diperoleh dapat dinyatakan reliabel atau layak sebagai alat dalam pengumpulan data.

\section{Uji Asumsi Klasik}

Uji Normalitas

Uji normalitas dilakukan untuk mengetahui apakah data yang diperoleh berdistribusi normal atau tidak. Uji normalitas yang dilakukan terhadap sampel dilakukan dengan menggunakan kolmogorov-smirnov test dengan menetapkan derajat keyakinan (a) sebesar 5\%. (Prayitno, 2010:71 dalam Rido 2014). 
Tabel 4. Hasil Uji Normalitas

One-Sample Kolmogorov-

Smirnov Test

\begin{tabular}{|ll|r|}
\hline & & $\begin{array}{r}\text { Unstandardize } \\
\text { d Residual }\end{array}$ \\
\hline $\mathrm{N}$ & & 85 \\
Normal & Mean & .0000000 \\
Parameters & Std. & 3.56173975 \\
& Deviation & .056 \\
Most & Absolute & .044 \\
Extreme & Positive & -.056 \\
Differences & Negative & .520 \\
Kolmogorov-Smirnov Z & .950 \\
Asymp. Sig. (2-tailed) & \\
a. Test distribution is & is \\
Normal. &
\end{tabular}

Sumber: Data yang Diolah, Juni 2018

Besarnya nilai Kolmogrov-Smirnov adalah 0,520 dan signifikan pada 0,950 $>\alpha$ (nilai $\alpha$ adalah 5\%). Hal ini menunjukkan Data residual berdistribusi normal diterima.

\section{Uji Multikolinearitas}

Asumsi multikolinieritas adalah keadaan dimana terjadi hubungan linier yang sempurna atau mendekati sempurna antar variabel independen dalam model. Uji multikolinieritas digunakan untuk mengetahui ada atau tidaknya hubungan linear dalam variabel independen dalam model. Ada atau tidaknya multikolinieritas dapat dilihat dari nilai Variance Inflation Factor (VIF). (Latan 2013 dalam Rido 2014), menyatakan bahwa indikasi multikolinieritas pada umumnya terjadi jika VIF lebih dari 10, maka variabel tersebut mempunyai persoalan multikolinieritas dengan variabel bebas lainnya.

Tabel 5. Hasil Uji Multikolinearitas

\begin{tabular}{|lccc|}
\hline \multicolumn{2}{l}{ Multikolinierity } & VIF & $\begin{array}{c}\text { Cutt } \\
\text { off }\end{array}$ \\
Persepsi & Transparansi & 1.025 & 10 \\
$\left(\mathrm{X}_{1}\right)$ & & & \\
Persepsi & Akuntabilitas & 1.025 & 10 \\
$\left(\mathrm{X}_{2}\right)$ & & & \\
\hline
\end{tabular}

Sumber: Data diolah, Juni 2018

Tabel 5, menunjukkan bahwa tidak terjadi multikolinieritas antar variabel independen karna menunjukkan nilai VIF kurang dari 10.

\section{Uji Hesteroskedastisitas}

Uji Hesteroskedastisitas bertujuan untuk menguji apakah dalam sebuah model regresi terjadi ketidaksamaan variabel dari residual dari satu pengamatan ke pengamatan yang lain. Cara memprediksi ada tidaknya hesteroskedastisitas pada suatu model dapat dilihat dari pola gambar scatterplot model tersebut (Latan, 2013 dalam Rido 2014). 


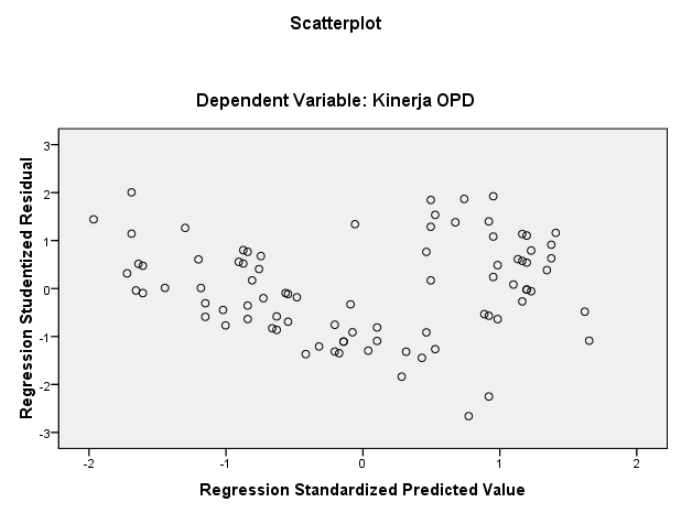

Gambar 2. Hasil Uji Hsteroskedastisitas

Gambar diatas menunjukkan bahwa tidak adanya hesteroskedastisitas, karena tebaran data tidak membentuk garis tertentu atau tidak terdapat pola yang jelas, serta titik-titik menyebar diatas dan dibawah angka nol pada sumbu Y.

\section{Uji Hipotesis}

Uji F

Tabel 6. Hasil Uji F

\begin{tabular}{|l|l|l|l|l|}
\hline $\begin{array}{l}\text { Variabel } \\
\text { Terikat }\end{array}$ & F Hitung & $\begin{array}{l}\text { Sig. } \\
\text { F }\end{array}$ & F Tabel & $\begin{array}{l}\text { Sig. } \\
\text { F }\end{array}$ \\
\hline $\begin{array}{l}\text { Kinerja } \\
\text { OPD }\end{array}$ & 47.464 & $.000^{\mathrm{a}}$ & 3.11 & 0,05 \\
\hline
\end{tabular}

Sumber: Data diolah Juni 2018

Uji F dimaksudkan untuk menguji model variabel independen transparansi, dan akuntabilitas, terhadap variabel dependen yaitu kinerja pemerintah. Tabel distribusi $\mathrm{F}$ dicari pada $\alpha=5 \%$, dengan derajat kebebasan (df) df1 atau 3-1=2, dan df $2 \mathrm{n}-\mathrm{k}-1$ atau. Berdasarkan hasil analisis regresi linear berganda diperoleh hasil, yaitu bahwa $F_{\text {hitung }}>F_{\text {tabel }}(47,464>3,11)$ dan signifikasi $(0,000<0,05)$, maka $\mathrm{H}_{3}$ diterima dan $\mathrm{H}_{0}$ ditolak, artinya variabel transparansi, dan akuntabilitas berpengaruh signifikan terhadap kinerja pemerintah Daerah Kabupaten Tegal.

\section{Uji Koefisien Determinasi}

Berfungsi untuk mengetahui besarnya proporsi atau sumbangan pengaruh variabel independen terhadap variabel dependen secara keseluruhan, maka dapat ditentukan dengan uji koefisien determinasi berganda.

Tabel 7. Hasil Uji Koefisien Determinasi

\begin{tabular}{|c|c|c|c|c|}
\hline & \multicolumn{4}{|c|}{ Model Summary $^{\mathbf{b}}$} \\
\hline $\begin{array}{c}\text { Mod } \\
\text { el }\end{array}$ & $\mathrm{R}$ & $\begin{array}{c}\mathrm{R} \\
\text { Square }\end{array}$ & $\begin{array}{l}\text { Adjusted R } \\
\text { Square }\end{array}$ & $\begin{array}{l}\text { Std. Error } \\
\text { of the } \\
\text { Estimate }\end{array}$ \\
\hline 1 & $.732^{\mathrm{a}}$ & .537 & .525 & 3.60491 \\
\hline
\end{tabular}

Transparansi

b. Dependent Variable: Kinerja OPD

Hasil analisis menunjukkan bahwa besarnya presentase sumbangan pengaruh variabel transparansi, dan akuntabilitas, terhadap kinerja pemerintah Daerah Kabupaten Tegal, dapat dilihat 
dari nilai Adjusted $R$ Square (R) menunjukkan sebesar 0,525 atau senilai 5,2\% dan sisanya 94,8\% dipengaruhi atau dijelaskan oleh faktor-faktor lain yang tidak dimasukkan dalam model penelitian ini, seperti kemampuan kerja aparatur, dan rancangan kerja.

Uji t

Tabel 7. Hasil Uji t

\begin{tabular}{|l|l|c|c|c|}
\hline $\begin{array}{l}\text { Variabel } \\
\text { Bebas }\end{array}$ & $\begin{array}{l}\mathrm{t} \\
\text { Hitung }\end{array}$ & $\begin{array}{l}\text { Sig.t } \\
\text { hitung }\end{array}$ & t. tabel & $\begin{array}{l}\text { Sig.t } \\
\text { tabel }\end{array}$ \\
\hline $\begin{array}{l}\text { Transpara } \\
\text { nsi }\end{array}$ & 6.545 & .000 & 1,989 & 0,05 \\
\hline $\begin{array}{c}\text { Akuntabili } \\
\text { tas }\end{array}$ & 6.116 & .000 & 1,989 & 0,05 \\
\hline
\end{tabular}

Sumber: Data diolah Juni 2018

Hasil uji t untuk hipotesis pertama menunjukkan bahwa $\mathrm{H}_{1}$ diterima dan $\mathrm{H}_{0}$ ditolak, ini ditunjukkan oleh variabel transparansi $\left(\mathrm{X}_{1}\right)$ memiliki nilai t 6,545>1,989, dan signifikan $0,00>$ 0,05 yang berarti secara parsial variabel transparansi berpengaruh signifikan terhadap kinerja pemerintah Daerah Kabupaten Tegal. Hasil $t_{\text {hitung }}$ positif, maka jika ada peningkatan pada variabel transparansi maka akan meningkatkan pula kinerja pemerintah;

Hasil uji t untuk hipotesis kedua menunjukkan bahwa $\mathrm{H}_{2}$ diterima dan $\mathrm{H}_{0}$ ditolak, ini ditunjukkan oleh variabel akuntabilitas $\left(\mathrm{X}_{2}\right)$ memiliki nilai t 6,116 <1,989 dan signifikan 0,000 > 0,05 yang berarti secara parsial variabel akuntabilitas berpengaruh signifikan terhadap kinerja pemerintah Daerah Kabupaten Tegal. Hasil t positif, maka jika ada peningkatan pada variabel akuntansi maka akan meningkatkan pula kinerja pemerintah.

\section{PEMBAHASAN}

Kabupaten Tegal, adalah salah satu kabupaten Provinsi Jawa Tengah. Ibu kotanya adalah Slawi, sekitar $14 \mathrm{~km}$ sebelah Kota Tegal. Kabupaten ini berbatasan dengan Kota Tegal dan Laut Jawa di utara, Kabupaten Pemalang di timur, Kabupaten Banyumas di selatan, serta Kabupaten Brebes disebelah selatan dan barat. Bertempat di Jl. Dr. Soetomo No 1, Slawi, Tegal, Jawa Tengah, 52417 para pegawai Badan Pengelola Keuangan dan Aset Daerah Kabupaten Tegal ini melaksanakan tugasnya. Dengan mengusung Visi "Terwujudnya Tata Kelola Keuangan dan Aset Daerah Yang Akuntabel dan Transparan" dimana fungsi tersebut dimaksudkan untuk menjadi lembaga yang profesional dalam memfasilitasi kegiatan BPKAD Kabupaten Tegal. BPKAD Kabupaten Tegal beranggotakan 46 orang pegawai. Kabupaten Tegal memiliki 4 (empat) buah badan usaha milik daerah (BUMD) yaitu: PDAM, PD. BPR. BKK Kab Tegal, PD. BKK. SLAWI dan PD. BKK. Bank Tegal Gotong Royong. Secara administratif Kabupaten Tegal terbagi dalam 18 kecamatan, 281 desa, dan 6 kelurahan.

\section{Pengaruh Transparansi Terhadap Kinerja}

Hasil uji t untuk hipotesis pertama menunjukkan bahwa $\mathrm{H}_{1}$ diterima dan $\mathrm{H}_{0}$ ditolak, ini ditunjukkan oleh variabel transparansi $\left(\mathrm{X}_{1}\right)$ memiliki nilai t $6,545>1,989$, dan signifikan $0,00<0,05$ yang berarti secara parsial variabel transparansi berpengaruh signifikan terhadap kinerja pemerintah Daerah Kabupaten Tegal. Hasil thitung positif, maka jika ada peningkatan pada variabel transparansi maka akan meningkatkan pula kinerja pemerintah.

Hal ini dapat dilihat dari hasil penelitian yang sudah dilakukan bahwa hak publik untuk mendapat pengumuman oleh pemerintah terkait kebijakan publik sudah di ikuti oleh efektifitas media yang digunakan. Pemberian informasi kepada publik yang dirasa telah dapat meningkatkan kebijakan transparansi keuangan daerah, telah menjadikan kinerja pemerintah atau kegiatan yang dilakukan oleh pemerintah dapat dikontrol dan diketahui oleh publik karena kemudahan dalam mendapatkan informasi merupakan bentuk transparansi atau keterbukaan yang telah dibuat oleh pemerintah.

Dari hasil yang diperoleh, transparansi sebagai prinsip yang menjamin akses atau kebebasan bagi setiap orang untuk memperoleh informasi tetang penyelenggaraan pemerintah, yakni 
informasi tentang kebijakan, proses pembuatan dan pelaksanaannya, serta hasil-hasil yang dicapai atau keterbukaan pemerintah dalam membuat kebijakan-kebijakan keuangan daerah sehingga dapat diketahui dan diawasi oleh DPRD dan masyarakat adalah baik. Hal ini didukung oleh penelitian sebelumnya yang dilakukan oleh Lismawati (2013), dimana pada penelitian tersebut diperoleh hasil bahwa penerapan transparansi menujukkan hasil yang berpengaruh signifikan dengan arah positif terhadap kinerja Satuan Kerja Pemerintah Daerah di Provinsi Bengkulu, didukung pula dengan penelitian Rohmah (2012) yang menyimpulkan bahwa transparansi berpengaruh terhadap kinerja partai politik.

\section{Pengaruh Akuntabilitas Terhadap Kinerja}

Hasil uji t untuk hipotesis kedua menunjukkan bahwa $\mathrm{H}_{2}$ diterima dan $\mathrm{H}_{0}$ ditolak, ini ditunjukkan oleh variabel akuntabilitas $\left(\mathrm{X}_{2}\right)$ memiliki nilai t 6,116 < 1,989 dan signifikan 0,000< 0,05 yang berarti secara parsial variabel akuntabilitas berpengaruh signifikan terhadap kinerja pemerintah Daerah Kabupaten Tegal. Hasil t positif, maka jika ada peningkatan pada variabel akuntansi maka akan meningkatkan pula kinerja pemerintah. Hasil ini sesuai dengan penelitian Asrida (2012), Meutia dan Nurfitriana (2011), Ardhiarisca (2012), dan Auditya dkk. (2013).

Akuntabilitas berpengaruh terhadap kinerja diukur dari adanya jamian kepatuhan hukum dan tidak ada penyalahgunaan jabatan yang dilakukan oleh pemerintah daerah Kabupaten Tegal. Dengan kata lain bahwa adanya akuntabiitas hukum dan kejujuran yang meliputi adanya kesesuaian jaminan kepatuhan terhadap hukum dan peraturan yang di isyaratkan dalam peraturan daerah terkait penggunaan sumber dana publik, dan tidak adanya penyalahgunaan jabatan selama peiode pemerintahan.

Penelitian yang dilakukan, kedua menunjukkan bahwa $\mathrm{H}_{2}$ diterima dan $\mathrm{H}_{0}$ ditolak, ini ditunjukkan oleh variabel akuntabilitas $\left(\mathrm{X}_{2}\right)$ memiliki nilai t $6,116<1,989$ dengan arah positif. Akuntabilitas sebagai sebuah prinsip dari konsep good coorporate governance, yaitu sebuah konsep tata kelola pemerintah baru yang diadopsi oleh berbagai Negara berkembang.

\section{Pengaruh Transparansi dan Akuntabilitas secara simultan terhadap Kinerja}

Hasil uji $\mathrm{f}$ untuk hipotesis ketiga menunjukkan bahwa $\mathrm{F}_{\text {hitung }}>\mathrm{F}_{\text {tabel }}(47,464>3,11)$ dan signifikasi $(0,000<0,05)$, maka $\mathrm{H}_{3}$ diterima dan $\mathrm{H}_{0}$ ditolak, artinya variabel transparansi, dan akuntabilitas berpengaruh signifikan terhadap kinerja pemerintah Daerah Kabupaten Tegal.

Informasi laporan keuangan pemerintah daerah dapat memenuhi prinsip transparansi dan akuntabilitas jika pemerintah daerah terus meningkatkan aksesibilitas laporan keuangannya. Hal ini dapat dilakukan antara lain dengan cara memfasilitasi berbagai pihak yang berkepentingan agar dapat mengetahui atau memperoleh laporan keuangan dengan mudah. Dalam demokrasi yang terbuka, akses ini tersedia di berbagai media, seperti surat kabar, majalah, stasiun televisi, dan internet.

Transparansi terwujud apabila pemerintah bersedia untuk menginformasikan kepada masyarakat/DPRD bagaiamana dana publik digunakan/dikelola dalam kegiatan dan program pemerintah. Pemerintah berkewajiban memberikan informasi keuangan dan informasi lainya yang akan digunakan untuk pengambilan keputusan oleh pihak-pihak yang berkepentingan.

Berdasarkan uji hipotesis tersebut, maka dapat disimpulkan bahwa variabel Transparansi dan Akuntabilitas berpengaruh positif dan signifikan terhadap Kinerja. Hal ini didukung penelitian yang dilakukan Meutia dan Nurfitriana (2011) menunjukkan bahwa secara simultan variabel akuntabilitas, transparansi, partisipasi masyarakat, efisiensi dan efektivitas berpengaruh terhadap penyusunan anggaran berbasis kinerja.

\section{KESIMPULAN}

Berdasarkan hasil penelitian dan pembahasasn pada bagian sebelumnya, maka dapat ditarik kesimpulan sebagai berikut:

1. Transparansi keuangan daerah ternyata mempunyai pengaruh secara signifikan terhadap kinerja organisasi perangkat daerah. Hal ini dibuktikan dengan $t_{\text {hitung }}$ sebesar 6,545 lebih besar dari $t_{\text {tabel }}$ sebesar 1,989 atau nilai signifikan sebesar 0,000 lebih kecil dari 0,05. Hal tersebut maka hipotesis 1 menyatakan Transparansi keuangan daerah terhadap kinerja organisasi perangkat 
daerah terdukung, dengan demikian Transparansi keuangan daerah variabel yang mempengaruhi kinerja organisasi perangkat daerah.

2. Akuntabilitas keuangan daerah ternyata berpengaruh secara signifikan terhadap kinerja organisasi perangkat daerah. Hal ini dibuktikan dengan $t_{\text {hitung }}$ sebesar 6,116 lebih besar dari $t_{\text {tabel }}$ sebesar 1,989 atau nilai signifikan sebesar 0,000 lebih kecil dari 0,05. Hal tersebut maka hipotesis 2 menyatakan Akuntabilitas keuangan daerah terhadap kinerja organisasi perangkat daerah terdukung, dengan demikian Akuntabilitas keuangan daerah variabel yang mempengaruhi kinerja organisasi perangkat daerah.

3. Transparansi dan akuntabilitas keuangan daerah ternyata mempunyai pengaruh secara signifikan terhadap kinerja organisasi perangkat daerah. Hal ini dibuktikan dengan $\mathrm{f}_{\text {hitung }}$ sebesar 47,464 lebih besar dari $f_{\text {tabel }}$ sebesar 3,111 atau nilai signifikan sebesar 0,00 lebih kecil dari 0,05. Hal tersebut maka hipotesis 3 menyatakan Transparansi dan Akuntabilitas keuangan daerah terhadap kinerja organisasi perangkat daerah terdukung secara simultan, dengan demikian Transparansi dan akuntabilitas keuangan daerah variabel yang mempengaruhi kinerja organisasi perangkat daerah.

\section{Saran}

Berdasarkan hasil penelitian dan kesimpulan yang telah dilakukan, maka saran yang dapat diberikan sebagai berikut:

\section{Bagi Pemerintah Kabupaten Tegal}

a. Lebih meningkatkan sistem pemberian informasi kepada publik mengenai kebijakan transparansi keuangan daerah guna komunikasi publik oleh pemerintah perangkat daerah Kabupaten Tegal, sehingga publik bisa mengakses dokumen tentang keuangan daerah sewaktuwaktu.

b. Lebih objektif, jujur dan bijak dalam menunaikan hak dan kewajibannya untuk menilai dan mengawasi kinerja pemerintah daerah guna tercapainya fungsi pemerintah daerah yang telah diatur oleh Undang-Undang yang berlaku.

c. Lebih mempertimbangkan alternatif program yang memberikan hasil yang optimal dengan biaya yang minimal, sehingga pertanggungjawaban atas kebijakan-kebijakan yang diambil lebih tepat sasaran.

\section{Bagi peneliti selanjutnya}

a. Peneliti dalam penelitian selanjutnya yang sejenis dapat menambahkan unsur lain yang lebih kompleks baik dalam lingkup internal maupun eksternal dalam penelitiannya dalam menganalisa kinerja perangkat daerah. Seperti indikator-indikator ekonomi dan sosial secara komprehensif yang mencakup diantaranya keadaan ekonomi nasional, lingkungan bisnis, stabilitas dan pengembangan, kesehatan dan pendidikan.

b. Peneliti dalam penelitian selanjutnya yang sejenis bisa menambahkan beberapa objek baru yang bisa dijadikan respoden dalam penilaian kinerja perangkat daerah seperti Lembaga swadaya masyarakat, ikatan jasa konstruksi, organisasi massa

\section{DAFTAR PUSTAKA}

Adiwirya, Muhammad Firdiansayah dan I Putu Sudana, 2015, Akuntabilitas, Transparansi dan Anggaran Berbasis Kinerja pada atuan Kerja Perangkat Daerah Kota Denpasar, E-Jurnal Akuntansi Universitas Udayana Vol 11.2, hal 611-628.

Asrida 2012, Pengaruh Penerapan Prinsip Akuntabilitas dan Transparansi Keuangan terhadap Kinerja Penyusunan Anggaran pada Pemerintah Kabupaten Bireuen, Jurnal Kebangsaan,Vol. 1 , No.1.

Asmoko, Hindri, 2015, Korelasi Opini Audit BPK atas LKKL dengan Hasil Evaluasi Lakip K/L, Balai Diklat Kepemimpinan, BPPK Kementerian Keuangan, Jakarta.

Auditya. L, Husaini, \& Lismawati, 2013. Analisis Pengaruh Akuntabilitas Dan Transparansi Pengelolaan Keuangan Daerah Terhadap Kinerja Pemerintah Daerah. Jurnal Fairness. Volume 3, Nomor 1: 21- 41 
Chow, C.W., Ganulin, D., Haddad, K. and Williamson, J. 1998. The balanced scorecard: a potent tool for energizing and focusing health-care organization management. Journal of Healthcare Management

Gray. R., D. L. Owen, dan C. Adams. 1996. Accounting and Accountability: Changes and Challenges in Corporate Social and Environmental Reporting. Prentice-Hall, Inc. London.

Halim, Abdul dan Muhammad Syam Kusufi. 2013. Akuntansi Sektor Publik : Akuntansi Keuangan Daerah. Jakarta : Salemba Empat.

Hartanti, Karina. 2011. Pandangan Publik Terhadap Akuntabilitas Pemerintah Daerah di Provinsi Jawa Tengah. Skripsi Fakultas Ekonomi Universitas Diponegoro. Semarang.

Indriantoro, N., dan Supomo, B. 2012. Metodologi Penelitian dan Bisnis untuk Akuntansi dan Manajemen. Yogyakarta: BPFE.

Jember Prayitno, Duwi. 2010. Paham Analisa Data Statistik SPSS. MediaKom, Yogyakarta.

Latan, Hengky. 2013. Analisis Multivariat Teknik dan Aplikasi. Bandung : Alfabeta.

Lismawati, Husaini dan Lucy Aitya. 2013. Analisis Pengaruh Akuntabilitas dan Transparansi Pengelolaan Keuangan Daerah Terhadap Kinerja Pemerintah Daerah. Jurnal Fairness Volume 3, Nomor 1: 21-41.

Meidawati, Nurida. 2012. Analisis Pengaruh Persepsi Penerapan Transparansi dan Akuntabilitas Publik Terhadap Kinerja Satuan Kerja Perangkat Daerah. Skripsi Fakultas Ekonomi Universitas Jember.

Nico Andrianto. 2007. Good e-Government: Transparansi dan Akuntabilitas Publik Melalui eGovernment. Malang: Bayumedia Publishing.

Rezky Mulya Anugriani. 2014. Pengaruh Akuntabilitas, Transparansi, dan Pengawasan Terhadap Kinerja Anggaran Berkonsep Value for Money Pada Instansi Pemerintah di Kabupaten Bone. Skripsi. Makasar: Universitas Hasanudin Makasar.

Rohman, A. 2009. Akuntansi Sektor Publik Telaah dari Dimensi : Pengelolaan Keuangan Daerah, Good Governance, Pengendalian, Pengawasan dan Pengukuran Kinerja Pemerintah Daerah. Semarang: Badan Penerbit Universitas Diponegoro.

Rohmah, Lailatur. 2012. Persepsi Mahasiswa Akuntansi Unesa Tentang Pengaruh Transparansi dan Akuntabilitas Keuangan Partai Politik Terhadap Kinerja Partai dan Upaya Pemberantasan Kejahatan Kerah Putih. Skripsi Fakultas Ekonomi Universitas Negeri Surabaya. Surabaya.

Sarjono, Haryadi dan Winda Julianita. 2013. SPSS vs LISREL : Sebuah Pengantar Aplikasi Untuk Riset. Jakarta : Salemba Empat. 